\title{
Maternal, Fetal and Newborn Outcome with Respect to Anemic Status of Women Admitted in Maternity Ward of BPKIHS
}

\author{
Upadhyaya $\mathbf{S}^{1^{*}}$, Pokharel $\mathbf{N}^{2}$, Shrestha $\mathbf{M}^{3}$, Basnet $\mathbf{P}^{4}$ \\ 'Lecturer, College of Nursing Sciences, Gandaki Medical College \& Teaching Hospital, Pokhara, Nepal \\ ${ }^{2}$ Professor \& Head, ${ }^{3}$ Professor, Department of Maternal Health Nursing, College of Nursing, BPKIHS, Dharan, Nepal \\ ${ }^{4}$ Associate Professor, Department of Obstetrics \& Gynecology, BPKIHS, Dharan, Nepal
}

\section{Keywords}

Anemia, Outcome, Pregnancy.

\section{Corresponding author \\ *Ms. Shraddha Upadhyaya \\ Lecturer, College of Nursing Sciences \\ Gandaki Medical College \& Teaching Hospital \\ Pokhara, Nepal \\ Email: rajresunga@gmail.com}

\section{ABSTRACT}

Background: Anemia is a common problem in pregnancy particularly in developing countries. In Nepal, the prevalence of anemia in pregnancy is $48 \%$. It is defined by WHO as hemoglobin level less than $11 \mathrm{gm} / \mathrm{dL}$ in pregnancy. It leads to a number of threats to mother, fetus and newborn.

Objectives: The objective of the study was to assess the maternal, fetal and newborn outcome with respect to anemic status of women admitted in maternity ward of BPKIHS, Dharan, Nepal.

Methods: A descriptive cross-sectional study was conducted among the 20 to 35 years women admitted in maternity ward of BPKIHS. Total 193 respondents were included in the study by purposive sampling technique. Out of 193 respondents, 78 were anemic and 115 were nonanemic. Maternal, fetal and newborn outcome among all the respondents were assessed by interview and review of records. Pearson Chi-square test was used to find the association between two categorical variables.

Results: Maternal outcomes such as preterm delivery, mode of delivery and fetal and newborn outcomes such as abnormal fetal heart rate, IUGR, LBW, low APGAR scores at 1 minute and at 5 minutes, need for resuscitation and need for admission in ward/nursery/NICU were significantly associated with anemic status of women at $\mathrm{p}$ value $<0.05$. The prevalence of anemia among the pregnant women was $40.5 \%$.

Conclusion: Maternal outcome such as preterm delivery, cesarean section were associated with anemia. Regarding the fetal and newborn outcome; abnormal fetal heart rate, IUGR, low birth weight, APGAR scores below 7, need for resuscitation, need for admission in ward/ nursery/NICU were associated with anemia.

\section{INTRODUCTION}

Pregnancy and child birth is a normal physiological process, but it is associated with certain risk to the life of both mother and baby. Anemia is defined by WHO as "hemoglobin level less than $11 \mathrm{gm} \%$ in pregnancy. It is divided into three types viz mild degree ( 9 to $10.9 \mathrm{gm} \%$ ), moderate degree (7.0 to $8.9 \mathrm{gm} \%$ ) and severe degree (less than $7.0 \mathrm{gm} \%$ ).

According to World Health Organization (2008) globally, anemia affects 1.62 billion people which corresponds to $24.8 \%$ of the population. The highest prevalence is in preschool-age children and the lowest prevalence is 
in men. However, the population group with the greatest number of individuals affected is pregnant women. Among the pregnant women, $41.8 \%$ are anemic while $30.2 \%$ nonpregnant women are anemic. At the national level, anemia is considered a severe public health problem when the prevalence is equal to or greater than 40 percent in a vulnerable group. ${ }^{1}$

Table 1: Public health significance of anemia

\begin{tabular}{cc}
\hline Anemia prevalence & Public health significance \\
$>40 \%$ & Severe \\
$20-39 \%$ & Moderate \\
$5-19 \%$ & Mild \\
$0-4.9 \%$ & Normal \\
\hline
\end{tabular}

Based on these criteria, anemia is a severe public health program in Nepal; being almost a half of the pregnant women (48\%) anemic. $^{2}$

Though, there are many studies on anemia in pregnancy in Nepal but relatively few studies have been done in the maternal and fetal outcome. Hence, this research will provide a new platform for the personnel of related field including the policy makers to modify the current plans and policies and develop new action plans in this field. Keeping all this in view, this study was conducted to identify maternal, fetal and newborn outcome due to anemia in pregnancy.

\section{Statement of the problem}

A study to assess the maternal, fetal and newborn outcome with respect to anemic status of women admitted in maternity ward of BPKIHS, Dharan, Nepal.

\section{Objectives}

- To assess the maternal, fetal and newborn outcome with respect to anemic status of women admitted in maternity ward of BPKIHS.

- To find the association between maternal, fetal and newborn outcome with selected variables.

\section{METHODS}

\section{Study Design}

Descriptive cross-sectional study design was adopted in order to assess the maternal, fetal and newborn outcome with respect to anemic status of women admitted in maternity ward of BPKIHS, Dharan, Nepal.

\section{Study Setting}

Study was conducted at maternity wards of BPKIHS, Dharan, Nepal. BPKIHS is a 700 bedded tertiary level hospital. Among many facilities available at BPKIHS; Gynecology and Obstetric facility remains one of the significant facilities. In an average about 1000 to 1500 deliveries take place monthly. Postnatal mothers are shifted to different wards such as postnatal ward, MCH I, MCH II and Gynec Ward. Approximately 60 beds are allocated for postnatal mothers. Data were collected in those wards of BPKIHS where postnatal mothers were admitted.

\section{Study Population}

All postnatal women admitted in maternity wards of BPKIHS were the population of this study.

\section{Sample}

All postnatal women who met the eligibility criteria were the sample of this study.

\section{Sample Size}

Total of 193 samples were taken. Among them 78 were anemic and 115 were non-anemic.

\section{Sampling Technique}

Purposive sampling technique was adopted.

Eligibility criteria

Inclusion criteria

All postnatal women within the age group 20 to 35 years admitted in maternity wards of BPKIHS during the study period were included in the study.

\section{Exclusion criteria}

1. Those women who were not willing to participate in the study. 
2. Those postnatal women who didn't have laboratory reports of hemoglobin test done during first trimester and third trimester of pregnancy.

3. Women who had multiple pregnancy, oligohydraminous/ polyhydraminous, gestational diabetes mellitus, and antepartum hemorrhage in the present pregnancy.

4. Women who had past history of preterm delivery and pregnancy induced hypertension.

\section{Research Instrument}

Self-developed, semi-structured and pre-tested questionnaire were used.

\section{Validity of the tool}

A comprehensive literature search and review was done extensively to construct the tool. Validity of the tool was ascertained by consultation with guide, co-guides and other experts from Department of Maternal Health Nursing, Child Health Nursing, Medical Surgical Nursing, Mental Health Nursing, Community Health Nursing and Department of Gynecology and Obstetrics. Research tool was then translated into Nepali and checked by the subject expert.

\section{Pretesting of the research tool}

Pretesting was done on $10 \%$ (20) participants who were admitted in maternity ward of BPKIHS, Dharan, Nepal. Few modifications were done in the research tool before data collection. Those participants who were included in the pretesting were excluded from the research study.

\section{Data Collection Procedure}

Before data collection, permission was obtained from the concerned authority. The study participants were explained about the objectives of the study. Written informed consent was taken from the literate participants and for illiterate participants thumb print was obtained in front of their nearest literate person. Data was collected by using interview technique as well as review of records. Period of data collection was four weeks.

\section{Data Analysis Procedure}

Data entered in Microsoft Excel 2010 sheet was analyzed using Statistical Package for Social Sciences (SPSS) version 16. Descriptive statistics like frequency, percentage, mean and standard deviation were used to describe the characteristics of collected data. Pearson Chi-square test and Fisher's exact test was used to find out the association between two categorical variables. The confidence interval was taken as $95 \%$ P-value.

\section{Ethical Considerations}

Ethical clearance was obtained from Institutional Review Committee (IRC), B.P. Koirala Institute of Health Sciences. Informed written consent was taken from each participant before data collection (IRC Code number: IRC/673/015). Ethical principles were considered and followed throughout the study. Every precaution was taken to protect the rights of the subjects. Respondents participated in the research voluntarily.

\section{RESULTS}

Inferential statistics (Pearson Chi-square test and Fisher's exact test) was used to show the association between two categorical variables. P value $<0.05$ was considered as statistically significant.

Table 2: Socio-demographic characteristics of respondents ( $\mathrm{n}=193)$

\begin{tabular}{|c|c|c|c|c|c|}
\hline \multirow{2}{*}{$\begin{array}{l}\text { Char- } \\
\text { acter- } \\
\text { istics }\end{array}$} & \multirow{2}{*}{$\begin{array}{l}\text { Category } \\
\text { Frequency }\end{array}$} & \multicolumn{2}{|c|}{$\begin{array}{l}\text { Anemic women } \\
\qquad(\mathrm{n}=78)\end{array}$} & \multicolumn{2}{|c|}{$\begin{array}{c}\text { Non-anemic } \\
\text { women }(n=115)\end{array}$} \\
\hline & & $\begin{array}{l}\text { Per- } \\
\text { cent- } \\
\text { age }\end{array}$ & $\begin{array}{l}\text { Fre- } \\
\text { quency }\end{array}$ & $\begin{array}{l}\text { Per- } \\
\text { centag }\end{array}$ & \\
\hline \multirow{5}{*}{$\begin{array}{l}\text { Age (in } \\
\text { years) }\end{array}$} & $20-25$ & 34 & $43.6 \%$ & 30 & $26.1 \%$ \\
\hline & $25-30$ & 26 & $33.1 \%$ & 57 & $49.6 \%$ \\
\hline & $30-35$ & 18 & $23.1 \%$ & 28 & $24.3 \%$ \\
\hline & & \multicolumn{2}{|c|}{$\begin{array}{c}\text { Mean age } \pm \text { SD } \\
26.11 \pm 4.07\end{array}$} & \multicolumn{2}{|c|}{$\begin{array}{c}\text { Mean age } \pm \text { SD } \\
26.42 \pm 4.05\end{array}$} \\
\hline & Dalit & 8 & $10.3 \%$ & 1 & $0.9 \%$ \\
\hline \multirow{4}{*}{ Ethnicity } & Janajati & 30 & $38.5 \%$ & 65 & $56.5 \%$ \\
\hline & Terai & 19 & $24.4 \%$ & 20 & $17.4 \%$ \\
\hline & Muslim & 2 & $2.6 \%$ & 2 & $1.7 \%$ \\
\hline & $\begin{array}{c}\text { Brahmin } \\
\text { and Chhetri }\end{array}$ & 19 & $24.4 \%$ & 27 & $23.5 \%$ \\
\hline \multirow{5}{*}{ Religion } & Hindu & 68 & $87.2 \%$ & 102 & $88.7 \%$ \\
\hline & Buddhist & 5 & $6.4 \%$ & 5 & $4.3 \%$ \\
\hline & Muslim & 2 & $2.6 \%$ & 1 & $0.9 \%$ \\
\hline & Christian & 1 & $1.3 \%$ & 1 & $0.9 \%$ \\
\hline & Kirat & 2 & $2.6 \%$ & 6 & $5.2 \%$ \\
\hline
\end{tabular}




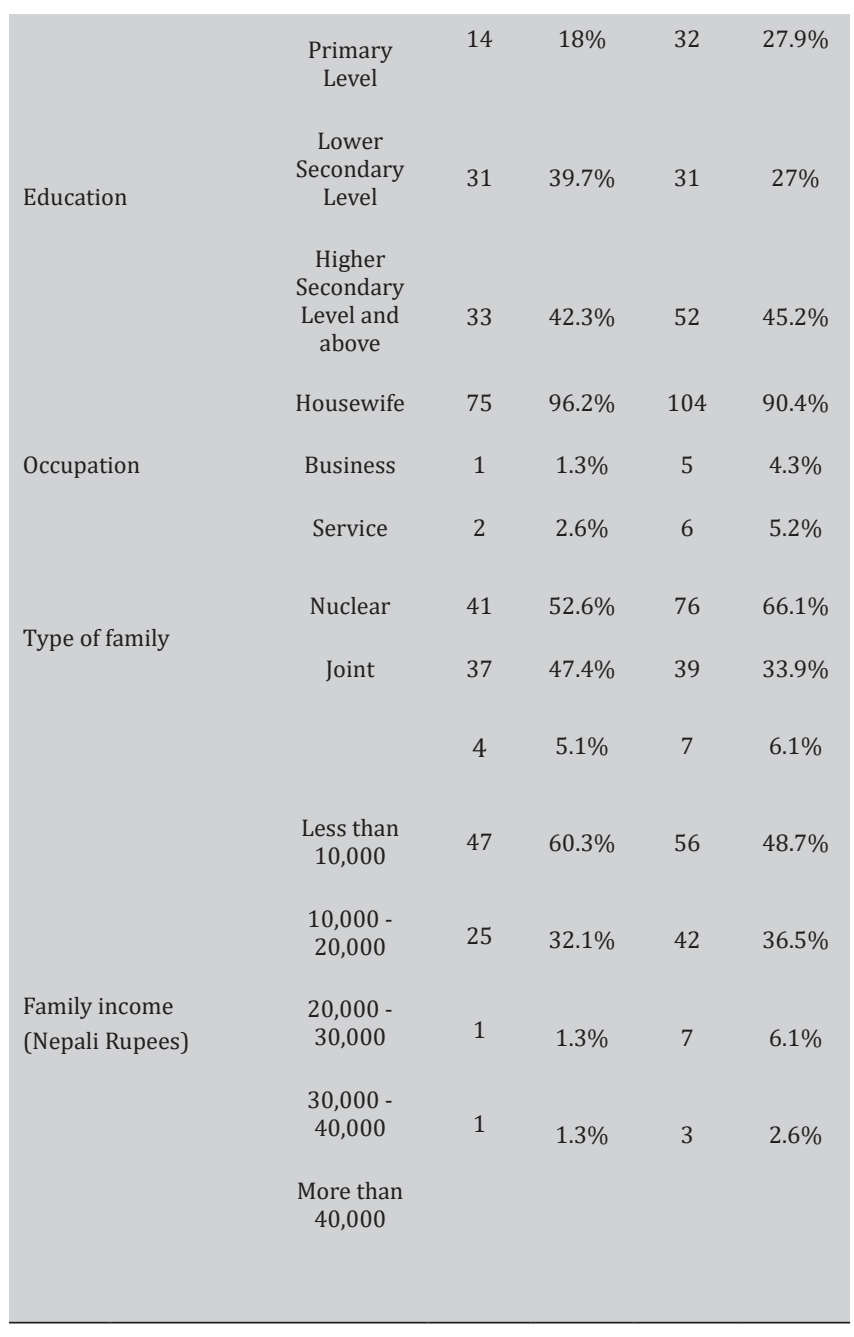

Table 2 depicts that $43.6 \%$ of the anemic women were in the age group 20 to 25 years whereas nearly a half of the non-anemic women (49.6\%) were in the age group 25 to 30 years. In the anemic group, more than one third $(38.5 \%)$ of the respondents were Janajatis whereas in the non-anemic group more than a half $(56.5 \%)$ of the respondents were Janajatis. Majority of both anemic (87.2\%) and non-anemic women (88.7\%) were Hindus. Most of the both anemic (42.3\%) and non-anemic women (45.2\%) have studied up to higher secondary and above. Majority of both anemic (96.2\%) and non-anemic women (90.4\%) were housewife. More than a half $(52.6 \%)$ of anemic women and $66.1 \%$ of nonanemic women lived in a nuclear family. The $60.3 \%$ of anemic women had family income between 10000 and 20000 Nepali Rupees, whereas less than a half (48.7\%) of the non-anemic women had family income within 10000 and 20000 Nepali Rupees.
Table 3: Hemoglobin level of respondents ( $n=193)$

\begin{tabular}{|c|c|c|c|c|c|}
\hline \multirow{2}{*}{$\begin{array}{l}\text { Hemoglo- } \\
\text { bin level }\end{array}$} & \multirow{2}{*}{ Category } & \multicolumn{2}{|c|}{$\begin{array}{c}\text { Anemic women } \\
(\mathrm{n}=78)\end{array}$} & \multicolumn{2}{|c|}{$\begin{array}{c}\text { Non-anemic women } \\
(n=115)\end{array}$} \\
\hline & & $\begin{array}{c}\text { Frequen- } \\
\text { cy }\end{array}$ & Percent & $\begin{array}{c}\text { Frequen- } \\
\text { cy }\end{array}$ & Percent \\
\hline \multirow{3}{*}{$\begin{array}{l}\text { Hemoglo- } \\
\text { bin (first } \\
\text { trimester) }\end{array}$} & Mild anemia & 47 & $60.25 \%$ & 0 & $0 \%$ \\
\hline & $\begin{array}{l}\text { Moderate } \\
\text { Anemia } \\
\text { Severe }\end{array}$ & 25 & $32.05 \%$ & & \\
\hline & Anemia & 6 & $7.6 \%$ & & \\
\hline \multicolumn{2}{|c|}{ Mean hemoglobin $\pm S D$} & \multicolumn{2}{|c|}{$9.3 \pm 1.24$} & \multicolumn{2}{|c|}{$12.77 \pm 1.29$} \\
\hline \multirow{3}{*}{$\begin{array}{l}\text { Hemoglo- } \\
\text { bin (third } \\
\text { trimester) }\end{array}$} & Mild anemia & 39 & $50 \%$ & 0 & $0 \%$ \\
\hline & $\begin{array}{l}\text { Moderate } \\
\text { Anemia } \\
\text { Severe }\end{array}$ & 31 & $39.74 \%$ & & \\
\hline & Anemia & 8 & $10.25 \%$ & & \\
\hline \multicolumn{2}{|c|}{ Mean hemoglobin \pm SD } & \multicolumn{2}{|c|}{$9.00 \pm 1.21$} & \multicolumn{2}{|c|}{$12.87 \pm 1.02$} \\
\hline
\end{tabular}

Table 3 states that according to the first trimester record of hemoglobin; most $(60.25 \%)$ of the anemic women had mild anemia and six percent had severe anemia. Similarly, according to the third trimester record of hemoglobin; exactly a half (50\%) had mild anemia and only $10.25 \%$ had severe anemia. According to the first trimester record of hemoglobin; the mean hemoglobin level among anemic women was $9.3 \pm 1.24$ whereas the mean hemoglobin level among non-anemic women was $12.77 \pm 1.29$. Likewise, according to the third trimester record of hemoglobin; $9.00 \pm 1.21$ was the mean hemoglobin among anemic women and 12.87 \pm 1.02 among non-anemic women.

Table 4: Maternal outcome of respondents $(n=193)$

\begin{tabular}{|c|c|c|c|c|c|}
\hline \multirow{2}{*}{$\begin{array}{l}\text { Maternal } \\
\text { Outcome }\end{array}$} & \multirow{2}{*}{ Category } & \multicolumn{2}{|c|}{$\begin{array}{c}\text { Anemic women } \\
(\mathrm{n}=78)\end{array}$} & \multicolumn{2}{|c|}{$\begin{array}{c}\text { Non-anemic women } \\
(n=115)\end{array}$} \\
\hline & & $\begin{array}{l}\text { Frequen- } \\
\text { cy }\end{array}$ & Percentage & $\begin{array}{l}\text { Frequen- } \\
\text { cy }\end{array}$ & $\begin{array}{l}\text { Percent- } \\
\text { age }\end{array}$ \\
\hline \multirow{2}{*}{$\begin{array}{l}\text { Mode of } \\
\text { delivery }\end{array}$} & $\begin{array}{l}\text { Cesare- } \\
\text { an-Section }\end{array}$ & 44 & $56.4 \%$ & 48 & $41.7 \%$ \\
\hline & $\begin{array}{l}\text { Normal } \\
\text { Delivery }\end{array}$ & 34 & $43.6 \%$ & 67 & $583 \%$ \\
\hline \multirow{2}{*}{$\begin{array}{l}\text { Preterm } \\
\text { delivery }\end{array}$} & Yes & 20 & $25.6 \%$ & 15 & $13 \%$ \\
\hline & No & 58 & $74.4 \%$ & 100 & $87 \%$ \\
\hline \multirow{2}{*}{$\begin{array}{l}\text { Pregnancy } \\
\text { induced hy- } \\
\text { pertension }\end{array}$} & Yes & 4 & $5.1 \%$ & 4 & $3.5 \%$ \\
\hline & No & 74 & $94.9 \%$ & 111 & $96.5 \%$ \\
\hline \multirow{2}{*}{$\begin{array}{l}\text { Post-Partum } \\
\text { hemorrhage }\end{array}$} & Yes & 3 & $3.8 \%$ & 0 & $0 \%$ \\
\hline & No & 75 & $96.2 \%$ & 115 & $100 \%$ \\
\hline
\end{tabular}

Table 4 shows that more than a half (56.4\%) of the anemic women whereas only $41.7 \%$ of non-anemic women had cesarean section for delivery. Preterm 
delivery occurred in nearly a quarter $(25.6 \%)$ of anemic women and only $13 \%$ of non-anemic women. The $5.1 \%$ of anemic women had pregnancy induced hypertension on the other hand, pregnancy induced hypertension occurred in only $3.5 \%$ of non-anemic women. The $3.8 \%$ of anemic women had post-partum hemorrhage whereas none of the non-anemic women had post-partum hemorrhage.

Table 5: Fetal and newborn outcome of respondents $(n=193)$

\begin{tabular}{|c|c|c|c|c|c|}
\hline \multirow{2}{*}{$\begin{array}{l}\text { Fetal Out- } \\
\text { come }\end{array}$} & \multirow{2}{*}{ Category } & \multicolumn{2}{|c|}{$\begin{array}{c}\text { Anemic women } \\
\quad(n=78)\end{array}$} & \multicolumn{2}{|c|}{$\begin{array}{l}\text { Non-anemic women } \\
\qquad(\mathrm{n}=115)\end{array}$} \\
\hline & & $\begin{array}{l}\text { Fre- } \\
\text { quency }\end{array}$ & $\begin{array}{l}\text { Percent- } \\
\text { age }\end{array}$ & $\begin{array}{c}\text { Fre- } \\
\text { quency }\end{array}$ & $\begin{array}{l}\text { Percent- } \\
\text { age }\end{array}$ \\
\hline \multirow{3}{*}{$\begin{array}{l}\text { Fetal heart } \\
\text { rate }\end{array}$} & $\begin{array}{c}\text { Normal } \\
\text { Range (120- } \\
160)\end{array}$ & 69 & $88.5 \%$ & 113 & $98.3 \%$ \\
\hline & $\begin{array}{c}\text { Abnormal } \\
\text { range }(<120 \\
\text { and }>160 \\
\text { beats } / \mathrm{min})\end{array}$ & 6 & $7.7 \%$ & 1 & $0.9 \%$ \\
\hline & Absent & 3 & $3.8 \%$ & 1 & $0.9 \%$ \\
\hline \multirow{2}{*}{$\begin{array}{l}\text { Intra-uterine } \\
\text { growth retar- } \\
\text { dation }\end{array}$} & Yes & 6 & $7.7 \%$ & 1 & $0.9 \%$ \\
\hline & No & 72 & $92.3 \%$ & 114 & $99.1 \%$ \\
\hline \multirow{2}{*}{$\begin{array}{l}\text { Intra-uterine } \\
\text { death }\end{array}$} & Yes & 3 & $3.8 \%$ & 1 & $0.9 \%$ \\
\hline & No & 75 & $96.2 \%$ & 114 & $99.1 \%$ \\
\hline Low birth & Yes & 26 & $33.3 \%$ & 14 & $12.2 \%$ \\
\hline weight & No & 52 & $66.7 \%$ & 101 & $87.8 \%$ \\
\hline \multirow{3}{*}{$\begin{array}{c}\text { APGAR } \\
\text { scores }<7 \text { at } \\
1 \text { minute }\end{array}$} & & & & & $4.3 \%$ \\
\hline & Yes & 10 & $12.8 \%$ & 5 & $95.7 \%$ \\
\hline & No & 68 & $87.2 \%$ & 110 & \\
\hline \multirow{2}{*}{$\begin{array}{c}\text { APGAR } \\
\text { scores }<7 \text { at } 5 \\
\text { minutes }\end{array}$} & Yes & 8 & $10.3 \%$ & 3 & $2.6 \%$ \\
\hline & No & 70 & $89.7 \%$ & 112 & $97.4 \%$ \\
\hline \multirow{2}{*}{$\begin{array}{l}\text { Need for re- } \\
\text { suscitation }\end{array}$} & Yes & 9 & $11.5 \%$ & 4 & $3.5 \%$ \\
\hline & No & 66 & $84.6 \%$ & 110 & $95.7 \%$ \\
\hline \multicolumn{6}{|l|}{ Need for } \\
\hline admission in & Yes & 11 & $14.1 \%$ & 4 & $3.5 \%$ \\
\hline $\begin{array}{l}\text { ward/nurs- } \\
\text { ery /NICU }\end{array}$ & No & 64 & $82.1 \%$ & 110 & $95.7 \%$ \\
\hline
\end{tabular}

Table 5 shows that $7.7 \%$ of anemic women's baby had abnormal fetal heart rate whereas only $0.9 \%$ of nonanemic women's baby had abnormal heart rate. With regard to IUGR, 7.7\% of anemic women's baby and only $0.9 \%$ of non-anemic women's baby had intra-uterine growth retardation. Intra-uterine death occurred among $3.8 \%$ of anemic women and only $0.9 \%$ of non-anemic women.

One third (33.3\%) of the anemic women's baby had low birth weight whereas only $12.2 \%$ of non-anemic women had low birth weight. APGAR scores $<7$ at 1 minute was present in $12.8 \%$ of anemic women's babies and only $4.3 \%$ of non-anemic women's babies. 10.3\% of anemic women's babies had APGAR scores $<7$ at 5 minutes whereas, only $2.6 \%$ of non-anemic women's babies had APGAR scores $<7$ at 5 minutes. $11.5 \%$ of anemic and $3.5 \%$ of non-anemic womens' baby required resuscitation. Similarly, $14.1 \%$ of anemic women's babies and 3.5\% of non-anemic womens' baby required admission in ward, nursery/NICU.

Table 6: Association of anemic status of women with maternal, fetal and newborn outcomes $(n=193)$

\begin{tabular}{|c|c|c|c|c|c|c|}
\hline $\begin{array}{l}\text { Character- } \\
\text { istics }\end{array}$ & Category & $\begin{array}{l}\text { Anemic } \\
\text { women } \\
(n=78)\end{array}$ & $\begin{array}{c}\text { Non } \\
\text { anemic } \\
\text { women } \\
(n=115)\end{array}$ & $\begin{array}{l}\text { Odds } \\
\text { ratio }\end{array}$ & $95 \%$ CI & $\begin{array}{c}P \\
\text { value }\end{array}$ \\
\hline \multirow{2}{*}{$\begin{array}{l}\text { Pregnancy } \\
\text { induced } \\
\text { hyperten- } \\
\text { sion }\end{array}$} & Yes & 4 & 4 & \multirow{2}{*}{1.5} & \multirow{2}{*}{$0.36-6.18$} & \multirow{2}{*}{ \#0.57 } \\
\hline & No & 74 & 111 & & & \\
\hline \multirow{2}{*}{$\begin{array}{l}\text { Preterm } \\
\text { delivery }\end{array}$} & Yes & 20 & 15 & \multirow{2}{*}{2.2} & \multirow{2}{*}{$\begin{array}{c}1.093- \\
4.83\end{array}$} & \multirow{2}{*}{$* 0.026$} \\
\hline & No & 58 & 100 & & & \\
\hline \multirow{2}{*}{$\begin{array}{l}\text { Mode of } \\
\text { delivery }\end{array}$} & $\mathrm{C} / \mathrm{S}$ & 44 & 48 & \multirow{2}{*}{0.554} & \multirow{2}{*}{$\begin{array}{c}0.310- \\
0.990\end{array}$} & \multirow{2}{*}{$* 0.04$} \\
\hline & ND & 34 & 67 & & & \\
\hline \multirow{3}{*}{$\begin{array}{l}\text { Postpartum } \\
\text { hemorrhage }\end{array}$} & Yes & 3 & 0 & \multirow{2}{*}{ - } & \multirow{2}{*}{ - } & \multirow{2}{*}{ NA } \\
\hline & No & 75 & 115 & & & \\
\hline & $\begin{array}{c}\text { Normal } \\
\text { range } \\
(120-160)\end{array}$ & 69 & 113 & \multirow{3}{*}{ - } & \multirow{3}{*}{ - } & \multirow{3}{*}{${ }^{*} 0.015$} \\
\hline \multirow[t]{2}{*}{$\begin{array}{c}\text { Fetal Heart } \\
\text { Rate }\end{array}$} & $\begin{array}{c}\text { Abnormal } \\
\text { range } \\
(<120 \text { and } \\
>160)\end{array}$ & 6 & 1 & & & \\
\hline & Absent & 3 & 1 & & & \\
\hline \multirow{2}{*}{ IUGR } & Yes & 6 & 1 & \multirow{2}{*}{0.10} & \multirow{2}{*}{$\begin{array}{c}0.012- \\
0.892\end{array}$} & \multirow{2}{*}{$\# 0.013$} \\
\hline & No & 72 & 114 & & & \\
\hline \multirow{2}{*}{ IUD } & Yes & 3 & 1 & \multirow{2}{*}{4.56} & \multirow{2}{*}{$\begin{array}{l}0.46- \\
44.66\end{array}$} & \multirow{2}{*}{ \#0.15 } \\
\hline & No & 75 & 114 & & & \\
\hline \multirow{2}{*}{$\begin{array}{l}\text { Low birth } \\
\text { weight }\end{array}$} & Yes & 26 & 14 & \multirow{2}{*}{3.60} & \multirow{2}{*}{$1.73-7.49$} & \multirow{2}{*}{$* 0.000$} \\
\hline & No & 52 & 101 & & & \\
\hline \multirow{2}{*}{$\begin{array}{l}\text { Preterm } \\
\text { birth }\end{array}$} & Yes & 20 & 15 & 22 & 1.093 - & $* 0.026$ \\
\hline & No & 58 & 100 & & 4.835 & \\
\hline APGAR & Yes & 10 & 5 & & & \\
\hline scores $<7$ at & & & & 3.23 & $1.06-9.86$ & ${ }^{*} 0.031$ \\
\hline 1 Minute & No & 68 & 110 & & & \\
\hline APGAR & Yes & 8 & 3 & & & \\
\hline $\begin{array}{l}\text { scores }<7 \text { at } \\
5 \text { Minutes }\end{array}$ & No & 70 & 112 & 4.26 & 1.095 & $\# 0.025$ \\
\hline
\end{tabular}




\begin{tabular}{|c|c|c|c|c|c|c|}
\hline $\begin{array}{l}\text { Need for } \\
\text { Resuscita- } \\
\text { tion }\end{array}$ & Yes & 66 & $\begin{array}{c}4 \\
110\end{array}$ & 3.75 & $\begin{array}{l}1.11- \\
12.66\end{array}$ & $\# 0.024$ \\
\hline $\begin{array}{l}\text { Need for } \\
\text { admission } \\
\text { in ward/ } \\
\text { nursery/ } \\
\text { NICU }\end{array}$ & $\begin{array}{l}\text { Yes } \\
\text { No }\end{array}$ & 11 & $\begin{array}{c}110 \\
4\end{array}$ & 0.21 & $0.06-0.69$ & $\# 0.005$ \\
\hline
\end{tabular}

* Pearson chisquare test

\# Fisher's exact test

Table 6 shows that there is no statistically significant association of anemic status of women with pregnancy induced hypertension and intrauterine death. The anemic status of women is significantly associated with preterm delivery $(p=0.02)$, mode of delivery $(0.04)$, fetal heart rate $(p=0.01)$ IUGR $(0.01)$, low birth weight $(p<0.001)$, premature birth (0.02), APGAR scores $<7$ at 1 minute (0.03), APGAR scores $<7$ at 5 minutes (0.02) need for resuscitation $(p=0.02)$ and need for admission in ward/ nursery/NICU ( $\mathrm{p}=0.005)$.

\section{DISCUSSION}

Anemia is one of the most common health problems among pregnant women. In this study, $22.25 \%$ of pregnant women had mild anemia, $14.47 \%$ had moderate anemia and $3.77 \%$ women were severely anemic. A study done in Eastern Ethiopia found that among 56.8\% anemic women, $28.9 \%$ were mildly anemic, $26.7 \%$ were moderately anemic and $1.2 \%$ was severely anemic. ${ }^{3}$

Another study done in Eastern Sudan showed among $62.6 \%$ anemic women, $52.4 \%$ had mild anemia, $8.1 \%$ had moderate anemia and $2.2 \%$ had severe anemia. ${ }^{4}$ In this study, the mean hemoglobin level among anemic and nonanemic group was $9.15 \pm 1.22$ and $12.82 \pm 1.15$ respectively. The finding of this study among anemic women is greater than the study done by Marahatta ${ }^{5}$ with mean hemoglobin level $8.75 \mathrm{gm} / \mathrm{dl}$, but lesser than the study done in Eastern Ethiopia where the mean hemoglobin level was 10.79 $( \pm 1.47) \mathrm{g} / \mathrm{dl}^{3}$

With regard to socio-demographic variables, the current study showed that majority of the respondents in anemic and non-anemic group were between 20 to 25 years and 25 to 30 years respectively. The mean age among anemic women was $26.11 \pm 4.07$ and that of non-anemic women was $26.42 \pm 4.05$. These findings were similar with the study done in Pakistan where the mean age of anemic women and non-anemic women was 26.85 years and
27.08 years respectively. ${ }^{6}$ In a study done in Bangalore, India among the severe anemic women showed that the mean age among anemic women was $22.81 \pm 2.79$ and non-anemic women $23.49 \pm 2.58 .^{7}$

In the current study, with regard to occupational status, majority of the women in both anemic and non-anemic group were housewife; this finding was similar to the study conducted in a tertiary care hospital in Pakistan. ${ }^{6}$

With regard to maternal outcome of anemia in pregnant women our study shows that the prevalence of preterm delivery among anemic women was $25.6 \%$ which is remarkably higher than the study done in Nepal Medical College Teaching Hospital, Kathmandu, Nepal. ${ }^{5}$

In the current study, pregnancy induced hypertension and post-partum hemorrhage were very minimal i.e. 5.1\% among anemic and 3.5\% among non-anemic women. And only $3.8 \%$ anemic and none of the non-anemic women had postpartum hemorrhage. In a study done in Nobel Medical College Teaching Hospital, Biratnagar, Nepal showed that the occurrence of pregnancy induced hypertension among severely anemic women was $36 \%$ in anemic, $10 \%$ in non-anemic and the postpartum hemorrhage was $14 \%$ in anemic and 5\% in non-anemic respectively. Our study showed that the operative intervention for delivery occurred among $56.4 \%$ of anemic women and $41.7 \%$ of non-anemic women which is greater than findings of the study conducted in Biratnagar, Nepal where cesarean section occurred among 22\% severely anemic and 5\% non-anemic women. ${ }^{8}$

Regarding the IUGR; the current study showed that 7.7\% of babies among the anemic women had IUGR and only $0.9 \%$ of babies among the non-anemic women had IUGR which is lesser than the study conducted in NMTCH, Kathmandu, Nepal where $16.6 \%$ babies had IUGR. ${ }^{8}$ In our study, low birth weight occurred among $33.3 \%$ of anemic and $12.2 \%$ of non-anemic women respectively which is higher than the study done in NMTCH, Biratnagar, Nepal.

With regard to APGAR score at 1 minute and APGAR score at 5 minutes; in the current study low APGAR score at 1 min occurred among $12.8 \%$ of anemic and $4.3 \%$ of non-anemic women. And the APGAR score at 5 minutes was $10.3 \%$ among anemic and $2.6 \%$ among non-anemic women. This finding is lesser than the study conducted in NMTCH, Biratnagar, Nepal where the APGAR score at 5 minutes is $18 \%$ among severely anemic women and $5 \%$ among non-anemic women. In this study, there was no 
significant difference in occurrence of IUD among anemic and non-anemic women. This finding is consistent with the study conducted in Pakistan. ${ }^{6}$

\section{CONCLUSION}

The study concludes that anemic status of women is associated with maternal outcomes (preterm delivery, and mode of delivery), fetal and newborn outcomes (abnormal fetal heart rate, IUGR, low birth weight, preterm birth, APGAR scores below 7, need for resuscitation and need for admission in ward/nursery/NICU). The prevalence of anemia in pregnancy is more than one-third of the respondents. Anemic status of women is also associated with the socio-demographic variables like ethnicity, family income, intake of non- vegetarian diet per week, number of pregnancies, intake of iron tablets, continuity of iron tablets during pregnancy.

\section{REFERENCES}

1 Macdonald C, Specialist SS, Canada WV, Mildon A, Neequaye M, Namarika R, et al. Anemia - can its widespread prevalence among women in developing countries be impacted? Anemia in Women : A Global Health Priority. 2010;2(1):1-42.

2 Government of Nepal, Ministry of Health, Department of Health Services. ARI. Annual Report. 2013/2014.

3. Gebre A, Mulugeta A. Prevalence of anemia and associated factors among pregnant women in North Western Zone of Tigray, Northern Ethiopia: A crosssectional study. Journal of Nutrition and Metabolism. 2015;1(2):5-30.

4. Ali AA, Rayis DA, Abdallah TM, Elbashir MI, Adam I. Severe anemia is associated with a higher risk for preeclampsia and poor perinatal outcomes in Kassala Hospital, Eastern Sudan. BMC Research Notes. 2011;1(2):6-26.

5. Marahatta R. Study of anemia in pregnancy and its outcome in Nepal Medical College Teaching Hospital, Kathmandu,Nepal. Journal of Nepal Medical College. Nepal Med Coll J. 2007 Dec;9(4):270-4.

6. Lone FW, Qureshi RN, Emmanuel F. Maternal anemia and its impact on perinatal outcome in a tertiary care hospital in Pakistan. Eastern Mediterranean Health Journal. 2004;10(6):801-7.

7. Sangeeta V, Pushpalatha S. Severe maternal anemia and neonatal outcome. Scholars Journal of Applied Medical Sciences (SJAMS). 2014;2(IC):303-9.

8. Ghimire RH, Ghimire S. Maternal and fetal outcome following severe anaemia in pregnancy: Results from Nobel Medical College Teaching Hospital, Biratnagar. Journal of Nobel Medical College. 2012;2(1):22-6.

9. Ahmad MO, Kalsoom U. Effect of Maternal Anaemia on APGAR Score of Newborn. Journal of Rawalpindi Medical College (JRMC). 2015;19(3):239-42.

10. Bhandari S, Sayami JT, Sayami M, Kandel BP, Banjara MR. General Health Status of Women of Reproductive Age in Nepal. Journal of Nepal Health Research Council. 2014;12(1): 8-13.

11. Msuya SE, Hussein TH, Uriyo J, Sam N, Stray-Pedersen B. Anemia among pregnant women in northern Tanzania: Prevalence, risk factors and effect on perinatal outcomes. Tanzania Journal of Health Research. 2011;13(1):33-9.

12. Okunade K, Adegbesan Omilabu M, Oluwole A. Perinatal outcome in anaemic pregnant women in South-Western Nigeria. International Journal of Research in Medical Sciences. 2014;2(2):7-20.

13. Srinivas P, Srinivasan P. The relationship between maternal anemia and birth weight in new born. IOSR Journal of Dental and Medical Sciences (IOSR-JDMS). 2015;14(12):9-11.

14. Rana SS, Sharma S, Chanda A, Malla R. Relationship between maternal haemoglobin and fetal weight. Nepal Journal of Obstetrics and Gynaecology. 2013; Jan-Jun;8(1):37-40. 